\title{
PIAS3 Gene
}

National Cancer Institute

\section{Source}

National Cancer Institute. PIAS3 Gene. NCI Thesaurus. Code C24671.

This gene is involved in transcriptional coregulation and protein degradation. 